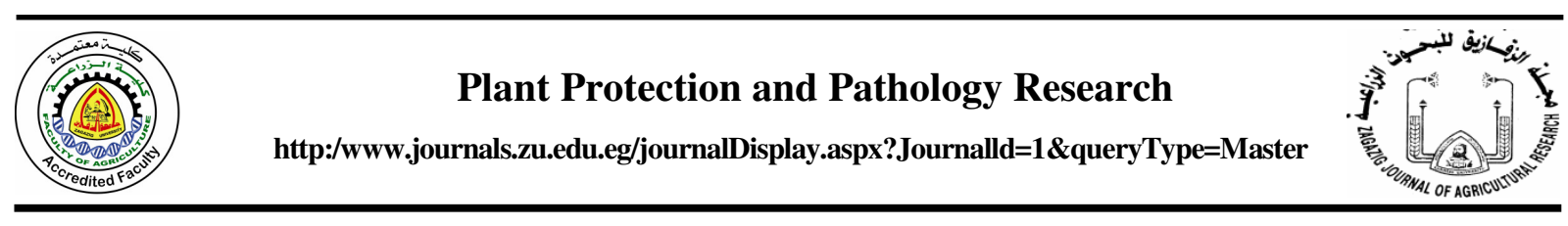

\title{
THE MAIN SUCKING INSECT PESTS AND THEIR ASSOCIATED PREDATORS ON OKRA PLANTS
}

\author{
Heba A. Ismail ${ }^{*}$ \\ Plant Prot. Res. Inst., Agric. Res. Cent., Dokki, Giza, Egypt \\ Received: 02/04/2018 ; Accepted: 06/05/2018
}

\begin{abstract}
The present study was conducted to survey and evaluate the population densities of the major sucking insect pests infesting okra plants and their common associated predators and its relation with the prevailing temperature and relative humidity at Diarb-Nigm district, Sharkia Governorate, Egypt during the two summer growing seasons of 2015 and 2016. Bemisia tabaci (Gennadius), Oxycarenus hyalinipennis Costa, Aphis gossypii Glover, Empoassca lybica (Bergevin) and Thrips tabaci Linde were the main sucking insect pests on okra plants. The most dominant predaceous insect species were Metasyrphus corollae (Fabricius), Chrysoperla carnea (Stephens), Coccinella undecimpunctata Linnaeus and Coccinella septempunctata Linnaeus. B. tabaci showed four peaks in the first and the fourth weeks of July and in the fourth week of August and September in the first season. In the second season, it peaked in the first week of August and September. Two peaks of activity for A. gossypii occurred in the fourth week of July and August during the first season and in the second one it peaked in the fourth week of July and third week of August. T. tabaci peaked in the fourth week of August and the second week of September during the first season. In the second season, it peaked in the fifth week of August. E. lybica peaked in the third week of July, the fourth week of August and the second week of September during 2015 growing season, while in the season of 2016 it peaked in the second week of August and the first week of September. O. hyalinipennis peaked once in the third week of October in both seasons of the study. M. corollae recorded one peak in both seasons, in the first season it was observed in the fifth week of August, while in the second one it was in the second week of August. C. carnea recorded its maximum number in the third and the fourth weeks of July during the first and second seasons of the study, respectively. $C$. undecimpunctata showed three peaks of activity in the fourth week of June, the second week of July and the second week of August in the first season, while in the second one it peaked in the fourth week of July. C. septempunctata recorded two peaks in the second week of July and August during the first season of the study. In the second season, it peaked in the second week of July. Temperature and relative humidity influenced the populations of B. tabaci, O. hyalinipennis, A. gossypii, E. lybica, $T$. tabaci, M. corollae, C. carnea, C. undecimpunctata and C. septempunctata by 18.76, 3.19, 18.21, $10.79,6.23,15.20,2.45,11.75$ and $1.45 \%$ in the first season of the study and by $41.48,54.31,41.47$, 53.70, 54.31. 24.86, 7.61, 11.22 and $12.95 \%$ in the second one, respectively. Also, the predator-prey ratios were estimated.
\end{abstract}

Key words: Sucking insect pests, associated predators, okra plants, temperature, relative humidity.

\section{INTRODUCTION}

Okra (Abdelmoschus esculentus L. Moench) is highly nutritious vegetable belonging to the family Malvaceae. It contains carbohydrates, proteins, fat, vitamins A, C and B6, folic acid,

\footnotetext{
* Corresponding author: Tel. : +201112572196

E-mail address: hebaismail98@yahoo.com
}

magnesium, potassium, iron, B carotene, riboflavin and fibre (Gopalan et al., 2007; Varmudy, 2011). Okra is susceptible to the attack by many insect pests from vegetative to reproductive stages that cause considerable damage and reduce the productivity and an 
increase in farm cost (Ali et al., 2015). These insect pests include sucking insect pests such as Bemisia tabaci (Gennadius), Aphis gossypii Glover, Empoasca lybica (Bergevin), Oxycarenus hyalinipennis Costa and Thrips tabaci Linde that reduce crop yield directly by piercing plant tissues and sucking cell sap from the phloem cells or from general tissues of foliage or fruits and secreting honeydew which disturbs the photosynthesis process. Moreover, indirectly injury caused by transmission diseases as Leaf Cotton Curl Virus and Yellow Vein Mosaic diseases. (Bhatangar and Sharma, 1991; Harrison et al., 1997; Ahmad et al., 2002; Asi et al., 2008).

It is important to survey insect pests, because routine use of chemical control without taking into consideration the insect pest density is economically wasteful, also environmentally hazardous chemicals (which destroys natural enemies and other beneficial insects) and toxic contaminants are introduced into the soil thus causing insecticide resistance (Biological Control Task Force, 2005).

Therefore, the present work aims to survey and evaluate the seasonal abundance of the major sucking insect pests and their associated predators on okra plants in relation with the prevailing temperature and relative humidity.

\section{MATERIALS AND METHODS}

The present investigation was carried out at Diarb-Nigm district, Sharkia Governorate, Egypt, during the two summer growing seasons of 2015 and 2016 to survey the major sucking insect pests attacking okra plants (Abdelmoschus esculentus L. Moench) and their common associated predatory insects. An experimental area of $350 \mathrm{~m}^{2}$ was divided into three replicates (each about $115 \mathrm{~m}^{2}$ ). This area designed according to the complete randomized blocks design and sown by okra seeds variety Balady on $1^{\text {st }}$ May in both growing seasons. Conventional agricultural practices were regularly performed according to the general program of okra cultivation without any insecticides application throughout the experimental period.

Hence the insects under investigation differed in their activities, living habits and distributions on various parts of the host plants, it was necessary to use different sampling techniques for each species of the tested sucking insect pests and their associated predators.

The weekly sampling started after five weeks from cultivation date and continued till the end of the experimental period and all samples were taken in daytime between 8 a.m. and 12 p.m. Two sampling techniques were used for surveying and counting inhabitant plants, i.e. plant sample and insect sweep net.

\section{Plant Sample}

Weekly samples of 10 leaves from each replicate were collected at random from different levels of plant height. The collected samples were transferred to the laboratory in tightly closed paper bages for inspection and counting the number of sucking insect pests (aphids, thrips and nymphs of white fly) and accompanied predators by the aid of binocular microscope. In the fruiting stage, 10 fruits were picked up randomaly from each replicate till harvesting and also transferred to the laboratory in paper bags. Okra fruits were dissected and the numbers of both nymphs and adults of Oxycarenus hyalinipennis Costa were counted.

\section{Insect Sweep Net}

To survey the flight insects infesting okra plants, an insect sweep net with a diameter of 30 $\mathrm{cm}$ and $60 \mathrm{~cm}$ in depth of the conical fine muslin was used. Each sample (consisted of 20 double strokes) was taken randomly at weekly intervals from both diagonal directions of the experimental area. Captured insects were transferred in well tied plastic bags to the laboratory for examination and counting.

\section{Effect of Prevailing Temperature and Relative Humidity}

Daily records of mean temperature and relative humidity during the experimental periods were obtained from the AgroMeteorological Station at Zagazig city, Sharkia Governorate. Values of simple correlation (r), partial regression (b) and coefficient of determination $(\mathrm{CD} \%)$ were calculated and used to describe the relationship between population fluctuation of sucking insect pests and their 
associated predators from one side and each of temperature and relative humidity according to Costat Software Microcomputer Program Analysis (1990).

\section{RESULTS AND DISCUSSION}

\section{Survey and Relative Densities of the Main Sucking Insect Pests and their Common Associated Predators}

\section{Insect pests}

As shown in Table 1, five sucking insect species belonging to five families and two orders were recorded on okra plants during the two cropping seasons (2015 and 2016). The major counted sucking insect species were Bemisia tabaci (Gennadius), Oxycarenus hyalinipennis Costa, Aphis gossypii Glover, Empoasca lybica (Bergevin) and Thrips tabaci Linde with relative densities of 30.00, 30.36, 22.17, 10.47 and 7.00\% during the first season of the study and 37.71 , $26.10,20.43,8.80$ and $6.96 \%$ for the second one, respectively.

These results are supported by those of Imam et al. (2010) who surveyed the main insect pests of some vegetables included okra in three selected areas in Nigeria and reported that the highest insect pests densities were obtained by aphid, bugs and thrips. Ahmad et al. (2010) reported that 13 pests were recorded on okra plants, among these pests leafhopper, whitefly and aphids were found to be major insect pests and inflicted heavy damage to okra during 2006 season, Also, Pal et al. (2013) reported that jassids, cotton white fly, cotton aphid and cotton seed bug were the major insect pests on okra in West Bengal, India during 2009 and 2010 growing seasons. Similar results were obtained by Allam (2014) who surveyed the phytophagous pests infesting okra plants in Assuit Governorate and found that B. tabaci, A. gossypii, E. lybica, T. tabaci, O. hyalinipennis, Nezara viridula L. and Tetranychus urticae Koch were the most important pests on okra plants. The obtained data also are in conformity with those of Khan et al. (2015) who indicated that the key insect pests that attacked okra plants at the new Development Farm of the University of Agriculture Peshawar, Pakistan during 2009 season were whitefly, aphid, leafhopper and red cotton bug.

\section{Insect predators}

Four predaceous species belonging to three families and three orders were recorded. The common predaceous species were Metasyrphus corollae (Fabricius), Chrysoperla carnea (Stephens), Coccinella undecimpunctata Linnaeus and Coccinella septempunctata Linnaeus representing 34.94, 22.89, 24.90 and $17.27 \%$ in the first season and 32.23, 28.91, 24.17 and $14.69 \%$ of the total number of insect predators in the second season, respectively.

These results are partially similar to the findings of Singh et al. (2013) who recorded C. undcimpunctata and C. septempunctata as an aphidophagous predators in the aphid colonies infesting okra agro-ecosystem in Chitrakoot region, India during 2008 and 2009 seasons. Also Allam (2014) reported that $C$. undecimpunctata, Scymnus interruptus Linnaeus, C. carnea and Chrysopa vulgaris Navas were the main predaceous insect species existing on okra plant. The present research findings differed from those of Khan et al. (2015) who found that the spider, Dictyna sp.; the ant, Solenopsis invicta (Burem) and C. septempunctata were the major natural enemies recorded on okra.

\section{Seasonal Abundance of the Main Sucking Insect Pests and their Common Associated Predators}

\section{Insect pests}

Results presented in Table 2 show the seasonal abundance of the major sucking insect pests:

\section{The cotton whitefly, Bemisia tabaci (Gennadius)}

The immature stages of B. tabaci started to appear in the second week of June by 22 and 15 nymphs/sample during the two successive seasons of 2015 and 2016, consecutively. In the first season the population of $B$. tabaci increased gradually showing four peaks in the first and fourth week of June, in the fourth week of July, in the first week of Augest and in the fourth week of September with numbers of 114, 184, 353 and 268 nymphs/sample, subsequently. In the second season, B. tabaci peaked in the first week of both August and September by 203 and 536 nymphs/sample. Afterwards, a gradual decrease was observed till the end of both seasons. 
Table 1. Total numbers of main sucking insect pests and their associated predators on okra plants at Diarb-Nigm district, Sharkia Governorate using plant sample and sweep net in 2015 and 2016 growing seasons

\begin{tabular}{|c|c|c|c|c|c|c|c|c|c|c|}
\hline \multirow[t]{2}{*}{ Insect species } & \multicolumn{4}{|c|}{2015} & \multicolumn{4}{|c|}{2016} & \multicolumn{2}{|c|}{ General } \\
\hline & PS & SN & $\begin{array}{c}\text { Total } \\
\text { number }\end{array}$ & $(\%)$ & PS & $\mathbf{S N}$ & $\begin{array}{c}\text { Total } \\
\text { number }\end{array}$ & $(\%)$ & $\begin{array}{c}\text { Total } \\
\text { number }\end{array}$ & $(\%)$ \\
\hline \multicolumn{11}{|l|}{ Insect pests } \\
\hline $\begin{array}{l}\text { Bemisia tabaci (Gennadius) } \\
\text { (Homoptera : Aleyrodidae) }\end{array}$ & 2549 & 105 & 2654 & 30.00 & 2731 & 126 & 2857 & 37.71 & 5511 & 33.56 \\
\hline $\begin{array}{l}\text { Oxycarenus hyalinipennis Costa } \\
\text { (Hemiptra : Lygaeidae) }\end{array}$ & 2237 & 449 & 2686 & 30.36 & 1723 & 254 & 1977 & 26.10 & 4663 & 28.39 \\
\hline $\begin{array}{l}\text { Aphis gossypii Glover } \\
\text { (Homoptera : Aphididae) }\end{array}$ & 1914 & 47 & 1961 & 22.17 & 1514 & 34 & 1548 & 20.43 & 3509 & 21.37 \\
\hline $\begin{array}{l}\text { Empoasca lybica (Bergevin) } \\
\text { (Homoptera : Cicadellidae) }\end{array}$ & 77 & 849 & 926 & 10.47 & 51 & 616 & 667 & 8.80 & 1593 & 9.70 \\
\hline $\begin{array}{l}\text { Thrips tabaci Linde } \\
\text { (Thysanoptera : Thripidae) }\end{array}$ & 593 & 26 & 619 & 7.00 & 491 & 36 & 527 & 6.96 & 1146 & 6.98 \\
\hline General total number & 7370 & 1476 & 8846 & 100.00 & 6510 & 1066 & 7576 & 100.00 & 16422 & 100.00 \\
\hline \multicolumn{11}{|l|}{ Insect predators } \\
\hline $\begin{array}{l}\text { Metasyrphus corollae (Fabricius) } \\
\text { (Diptera : Syrphidae) }\end{array}$ & 81 & 6 & 87 & 34.94 & 68 & 0 & 68 & 32.23 & 155 & 33.70 \\
\hline $\begin{array}{l}\text { Chrysoperla carnea (Stephens) } \\
\text { (Neuroptera : Chrysopidae) }\end{array}$ & 48 & 9 & 57 & 22.89 & 53 & 8 & 61 & 28.91 & 118 & 25.65 \\
\hline $\begin{array}{l}\text { Coccinella undecimpunctata Linnaeus } \\
\text { (Coleoptera : Coccinellidae) }\end{array}$ & 47 & 15 & 62 & 24.90 & 40 & 11 & 51 & 24.17 & 113 & 24.56 \\
\hline $\begin{array}{l}\text { Coccinella septempunctata Linnaeus } \\
\text { (Coleoptera : Coccinellidae) }\end{array}$ & 37 & 6 & 43 & 17.27 & 29 & 2 & 31 & 14.69 & 74 & 16.09 \\
\hline General total number & 213 & 36 & 249 & 100.00 & 190 & 21 & 211 & 100.00 & 460 & 100.00 \\
\hline
\end{tabular}

PS : Plant sample SN : Sweep net 
Table 2. Seasonal abundance of the main sucking insect pests on okra plants at Diarb-Nigm district, Sharkia Governorate in 2015 and 2016 growing seasons

\begin{tabular}{|c|c|c|c|c|c|c|c|c|c|c|}
\hline \multirow[t]{2}{*}{$\begin{array}{c}\text { Weekly } \\
\text { sampling date }\end{array}$} & \multicolumn{2}{|c|}{$\begin{array}{c}\text { Number of } B . \text { tabaci } \\
\text { / } 30 \text { leaves } \\
\end{array}$} & \multicolumn{2}{|c|}{$\begin{array}{c}\text { Number of } A . \\
\text { gossypii / } 30 \text { leaves }\end{array}$} & \multicolumn{2}{|c|}{$\begin{array}{c}\text { Number of } T \text {. tabaci } \\
\text { / } 30 \text { leaves } \\
\end{array}$} & \multicolumn{2}{|c|}{$\begin{array}{l}\text { Number of } E \text {. lybical } \\
60 \text { double strokes }\end{array}$} & \multicolumn{2}{|c|}{$\begin{array}{c}\text { Number of } O \text {. hyalinipennis/ } \\
30 \text { fruits } \\
\end{array}$} \\
\hline & 2015 & 2016 & 2015 & 2016 & 2015 & 2016 & 2015 & 2016 & 2015 & 2016 \\
\hline$\overline{\text { June, } \text {, }^{\text {st }}}$ & 0 & 0 & 14 & 7 & 0 & 0 & 17 & 0 & - & - \\
\hline $2^{\text {nd }}$ & 22 & 15 & 26 & 11 & 12 & 0 & 25 & 9 & - & - \\
\hline $3^{\text {rd }}$ & 24 & 24 & 28 & 16 & 15 & 2 & 35 & 13 & - & - \\
\hline $4^{\text {th }}$ & 49 & 37 & 29 & 23 & 18 & 7 & 37 & 15 & - & - \\
\hline July, $\mathbf{1}^{\text {st }}$ & 114 & 54 & 32 & 28 & 20 & 12 & 39 & 18 & - & - \\
\hline $2^{\text {nd }}$ & 111 & 60 & 43 & 34 & 24 & 14 & 42 & 23 & - & - \\
\hline $3^{\text {rd }}$ & 133 & 96 & 121 & 46 & 25 & 18 & 140 & 27 & - & - \\
\hline $4^{\text {th }}$ & 184 & 107 & 137 & 89 & 25 & 23 & 37 & 32 & - & - \\
\hline Aug., $1^{\text {st }}$ & 63 & 203 & 120 & 75 & 27 & 29 & 29 & 38 & - & - \\
\hline $2^{\text {nd }}$ & 49 & 154 & 118 & 104 & 29 & 31 & 32 & 82 & - & - \\
\hline $3^{\text {rd }}$ & 57 & 187 & 122 & 268 & 15 & 44 & 45 & 58 & - & - \\
\hline $4^{\text {th }}$ & 353 & 265 & 497 & 234 & 97 & 48 & 143 & 35 & - & - \\
\hline $5^{\text {th }}$ & 79 & 322 & 117 & 183 & 23 & 71 & 42 & 39 & - & - \\
\hline Sep., $1^{\text {st }}$ & 56 & 536 & 114 & 132 & 25 & 56 & 38 & 53 & - & - \\
\hline $2^{\text {nd }}$ & 97 & 271 & 104 & 97 & 83 & 51 & 80 & 44 & - & - \\
\hline $3^{\text {rd }}$ & 148 & 112 & 94 & 67 & 48 & 35 & 26 & 42 & 100 & 116 \\
\hline $4^{\text {th }}$ & 268 & 80 & 80 & 52 & 23 & 26 & 23 & 31 & 270 & 160 \\
\hline Oct., $1^{\text {st }}$ & 255 & 57 & 65 & 22 & 21 & 16 & 10 & 26 & 320 & 233 \\
\hline $2^{\text {nd }}$ & 246 & 45 & 35 & 17 & 20 & 6 & 9 & 19 & 360 & 308 \\
\hline $3^{\text {rd }}$ & 93 & 41 & 18 & 9 & 19 & 2 & 0 & 12 & 433 & 368 \\
\hline $4^{\text {th }}$ & 56 & 26 & 0 & 0 & 13 & 0 & 0 & 0 & 335 & 221 \\
\hline Nov., $1^{\text {st }}$ & 53 & 23 & 0 & 0 & 11 & 0 & 0 & 0 & 256 & 170 \\
\hline $2^{\text {nd }}$ & 39 & 16 & 0 & 0 & 0 & 0 & 0 & 0 & 163 & 147 \\
\hline Total & 2549 & 2731 & 1914 & 1514 & 593 & 491 & 849 & 616 & 2237 & 1723 \\
\hline Mean & 115.86 & 124.14 & 95.70 & 75.70 & 28.24 & 27.28 & 44.68 & 32.42 & 279.63 & 215.38 \\
\hline
\end{tabular}


The mean numbers of the cotton whitefly were 115.86 and 124.14 nymphs/sample during both seasons, respectively.

These results are in harmony with the findings of Khan and Ullah (1994) who found that the population of whiteflies on okra started to build up on early July and reached its peak in the months of August and September. Similar trends were found by Kumawat et al. (2000). The obtained results are also partially similar to the findings of Abdel Hamed et al. (2011) who studied the population fluctuation of B. tabaci on okra plants at Qalyubia Governorate during the plantation seasons of 2009 and 2010 and reported that the plants of okra were liable for infestation with $B$. tabaci throughout the whole period of plant growth. They also indicated that the population of $B$. tabaci showed three peaks of activity on the $6^{\text {th }}$ and $27^{\text {th }}$ of July and on the $31^{\text {st }}$ of August then it decreased till the end of the experimental period during the two studied seasons.

\section{The cotton aphid, Aphis gossypii Glover}

In regard to $A$. gossypii the population appeared from the first week of June by 14 and 7 individuals/sample, respectively and continued to the third week of October during both investigation seasons. In the first season, the aphid population increased continuously recording its maximum in the fourth week of July and August with numbers of 137 and 497 individuals/sample, subsequently. The mean number of the aphid during the period of its occurrence was 95.70 individuals/sample. Also, in the second season the aphid population showed two peaks. The first one was recorded in the fourth week of July (89 individuals / sample). The second and highest peak was in the third week of August (268 individuas/sample). The mean number of A.gossypii during the period of its appearance was 75.70 individuals / sample. It was observed that $A$. gossypii nearly disappeared from the fourth week of October till the end of the experimental period.

Similar results were obtained by Hammad and Mohsen (2000) who concluded that the cotton aphid showed a high level of infestation on roselle plants during July and August in the two successive seasons of 1997 and 1998.
Pathon et al. (2018) studied the incidence of the major insect pests infesting okra in India during 2014 and 2015 seasons and reported that the highest activity of $A$. gossypii was observed in August in the two seasons of the study.

\section{The cotton thrips, Thrips tabaci Linde}

Concerning T. tabaci, the insect started to appear on okra plants in the second week of June by 12 individuals/sample. Then, the population was fluctuated giving two peaks. The first one (97 individuals/sample) was observed in the fourth week of August and the second peak (83 individuals/sample) took place in the second week of September. The mean number of the pest during the period of its appearance was 28.24 individuals/sample in the first growing season. While in the second season, the first appearance of the insect was in the third week of June with very few numbers (2 individuals/sample), then after the population of the insect increased gradually and reached its maximum in the fifth week of August by 71 individuals/sample, then the population decreased slightly and the insects nearly disappeared from the fourth week of October till the end of the experiment. The mean number of $T$. tabaci during the period of its occurrence was 27.28 individuals / sample.

The present findings agree in a great part with those of Abdel Hamed et al. (2011) who stated that the first appearance of T. tabaci on okra plants was on the $1^{\text {st }}$ of June and the insect peaked on the $24^{\text {th }}$ of August and the $7^{\text {th }}$ of September during 2009 and 2010 growing seasons.

\section{The cotton leafhopper, Empoasca lybica (Bergevin)}

As for E. lybica, the obtained results cleared that the first presence of the insect in the first season was in the first week of June by 17 individuals/sample. Then, the population increased gradually and reached its maximum numbers with 140, 143 and 80 individuals / sample in the third week of July, fourth week of August and second week of September, respectively. The mean number of $E$. lybica during the period of its appearance was 44.68 individuals/sample. In the second season, $E$. lybica started to appear on okra plants with few numbers (9 individuals/sample) in the second week of June, then the insect numbers fluctuated 
to record two peaks of activity in the second week of August and first week of September by 82 and 53 individuals/sample, consecutively. The mean number of the cotton leafhopper during the period of its occurrence was 32.42 individuals/sample. It was noticed that okra plants were nearly free from any infestation with E. lybica during the last inspections of both growing seasons.

These results relatively agree with those obtained by Pal et al. (2013) who found that there was a significant increase of jassids population on okra at the flowering and fruiting stages.

\section{The cotton seed bug, Oxycarenus hyalinipennis Costa}

It is obvious that the population of O. hyalinipennis was not encountered during the early growth stage of okra plants and it was almost occurred in fruiting stage. The initial incidence of the bug was recorded in the third week of September with 100 and 116 individuals/ sample in the first and second seasons, respectively. Then the insect population increased gradually and peaked in the third week of October by 433 and 368 individuals/sample during 2015 and 2016 growing seasons, respectively. Thereafter, the insect population started to decrease again. The mean number of $O$. hyalinipennis during the period of its appearance in the first season was 279.63 individuals/sample, while in the second one it was 215.38 individuals / sample.

The present findings are in partial consonance with those of Pal et al. (2013) who reported that the population of the cotton seed bug increased slowly in the vegetative period but soon after development of fruits the population rapidly increased and attained maximum level just one week after fruiting. They added that the population gradually decreased later but caused considerable damage to the fruits till the maturity of the crop.

\section{Insect predators}

Results summarized in Table 3 show the seasonal abundance of the dominant predators associated with the major sucking insect pests infesting okra plants during the two seasons of the study.
The syrphus fly, Metasyrphus corollae (Fabricius)

The obtained results indicate that the first presence of $M$. corollae was in the third week of July by 6 and 3 individuals / sample in the first and second seasons, respectively. In the first season there was one peak of activity in the fifth week of August (18 individuals/sample), while in the second one the peak occurred in the second week of August (21 individuals/sample). The relative density of $M$. corollae as compared with the total numbers of considered predators were 38.03 and $35.79 \%$ in 2015 and 2016, respectively.

Such findings are relatively agree with those of Hammad and Mohsen (2000) who recorded $M$. corollae as one of the main predators that existing on roselle plant at El-Khattara district, Sharkia Governorate.

\section{The green lacewing, Chrysoperla carnea (Stephens)}

As for C. carnea, the population appeared during a short period that confined between the first week of July (4 individuals/sample) and the second week of August recording its maximum number (15 individuals/sample) in the third week of July in season of 2015. In the second season (2016), the population started with a few number ( 2 individuals / sample) in the first week of July and continued till the fourth week of August and peaked in the fourth week of July by 14 individuals / sample. The relative densities of $C$. carnea were 22.53 and $27.89 \%$ during the two studied seasons, successively.

The present work is supported by the findings of Henn and Weinzierl (1990) who reported that $C$. carnea larvae are active predators feed on many insect pests infesting field crops. Hoffmann and Frodsham (1993) stated that the green lacewings are common in agricultural fields and their adults feed only on nectar, pollen and aphid honeydew, but their larvae are active predators and they occur in a wide range of habitats.

\section{The eleven-spotted ladybird bettle, Coccinella undecimpunctata Linnaeus}

In the first season, $C$. undecimpunctata population was observed from the third week of 
Table 3. Seasonal abundance of the dominant predators associated with the main sucking insect pests on okra plants at Diarb-Nigm district, Sharkia Governorate during 2015 and 2016 growing seasons

\begin{tabular}{|c|c|c|c|c|c|c|c|c|}
\hline \multirow{2}{*}{$\begin{array}{c}\text { Weekly sampling } \\
\text { date } \\
\end{array}$} & \multicolumn{2}{|c|}{ M. corollae } & \multicolumn{2}{|c|}{ C. carnea } & \multicolumn{2}{|c|}{ C. undecimpunctata } & \multicolumn{2}{|c|}{ C. septempunctata } \\
\hline & 2015 & 2016 & 2015 & 2016 & 2015 & 2016 & 2015 & 2016 \\
\hline June, $1^{\text {st }}$ & 0 & 0 & 0 & 0 & 0 & 0 & 0 & 0 \\
\hline $2^{\text {nd }}$ & 0 & 0 & 0 & 0 & 0 & 0 & 0 & 0 \\
\hline $3^{\text {rd }}$ & 0 & 0 & 0 & 0 & 2 & 1 & 0 & 0 \\
\hline $4^{\text {th }}$ & 0 & 0 & 0 & 0 & 6 & 1 & 5 & 3 \\
\hline July, $\mathbf{1}^{\text {st }}$ & 0 & 0 & 4 & 2 & 3 & 2 & 6 & 6 \\
\hline $2^{\text {nd }}$ & 0 & 0 & 11 & 7 & 5 & 3 & 8 & 7 \\
\hline $3^{\text {rd }}$ & 6 & 3 & 15 & 11 & 4 & 5 & 4 & 4 \\
\hline $4^{\text {th }}$ & 6 & 7 & 8 & 14 & 1 & 9 & 2 & 4 \\
\hline Aug., $1^{\text {st }}$ & 7 & 13 & 7 & 8 & 3 & 7 & 0 & 3 \\
\hline $2^{\text {nd }}$ & 10 & 21 & 3 & 6 & 6 & 4 & 6 & 1 \\
\hline $3^{\text {rd }}$ & 14 & 14 & 0 & 3 & 4 & 4 & 3 & 1 \\
\hline $4^{\text {th }}$ & 15 & 8 & 0 & 2 & 4 & 2 & 2 & 0 \\
\hline $5^{\text {th }}$ & 18 & 2 & 0 & 0 & 2 & 1 & 0 & 0 \\
\hline Sep., $1^{\text {st }}$ & 5 & 0 & 0 & 0 & 2 & 1 & 1 & 0 \\
\hline $2^{\text {nd }}$ & 0 & 0 & 0 & 0 & 2 & 0 & 0 & 0 \\
\hline $3^{\text {rd }}$ & 0 & 0 & 0 & 0 & 2 & 0 & 0 & 0 \\
\hline $4^{\text {th }}$ & 0 & 0 & 0 & 0 & 1 & 0 & 0 & 0 \\
\hline Oct., $1^{\text {st }}$ & 0 & 0 & 0 & 0 & 0 & 0 & 0 & 0 \\
\hline $2^{\text {nd }}$ & 0 & 0 & 0 & 0 & 0 & 0 & 0 & 0 \\
\hline $3^{\text {rd }}$ & 0 & 0 & 0 & 0 & 0 & 0 & 0 & 0 \\
\hline $4^{\text {th }}$ & 0 & 0 & 0 & 0 & 0 & 0 & 0 & 0 \\
\hline Nov., $1^{\text {st }}$ & 0 & 0 & 0 & 0 & 0 & 0 & 0 & 0 \\
\hline $2^{\text {nd }}$ & 0 & 0 & 0 & 0 & 0 & 0 & 0 & 0 \\
\hline Total & 81 & 68 & 48 & 53 & 47 & 40 & 37 & 29 \\
\hline Relative density (\%) & 38.03 & 35.79 & 22.53 & 27.89 & 22.07 & 21.05 & 17.37 & 15.26 \\
\hline
\end{tabular}


June ( 2 individuals/sample) to the fourth week of September showing three peaks of activity in the fourth week of June, the second week of July and in the second week of August by 6,5 and 6 individuals / sample, respectively. The relative density of the predator was $22.07 \%$. While in the second season, $C$. undecimpunctata was firstly recorded in the third week of June with one individual / sample and continued till the first week of September reaching its maximum number ( 9 individuals / sample) in the fourth week of July. The relative density of $C$. undecimpunctata was $21.05 \%$.

Some earlier researchers had also reported that coccinellids are one of the natural enemies that contributed to the reduction of insect pests of okra (Solangi and Lahor, 2007).

\section{The seven-spotted ladybird bettle, Coccinella septempunctata Linnaeus}

As regards C. septempunctata, the population in the first season of the study appeared from the fourth week of June (5 individuals / sample) and continued till the first week of September recording two peaks of activity with 8 and 6 individuals / sample in the second week of both July and August, respectively. While in the second season the predator was observed on okra plants from the fourth week of June (3 individuals / sample) to the third week of August reaching its maximum in the second week of July by 7 individuals / sample. The relative densities of C. septempunctata were 17.37 and 15.26 during the first and the second seasons, successively.

Similar results were obtained by Khan $\boldsymbol{e t}$ al . (2015) who found that the population of C. septempunctata started from mid June and reached to its highest number in July.

\section{Effect of Temperature and Relative Humidity on the Main Sucking Insect Pests and their Associated Predators}

Results presented in Table 4 clear the influence of the two ecological weather factors, temperature and relative humidity on the population of the main sucking insect pests and their common predators existing on okra plants.

\section{Insect pests}

\section{Cotton whitefly, B. tabaci}

The correlation coefficient between $B$. tabaci population and mean temperature was positive and significant $\left(r_{1}=0.4238^{*}\right)$ in the first season, while in the second one it was positive and insignificant $\left(\mathrm{r}_{1}=0.1341^{\mathrm{ns}}\right)$, In case of relative humidity it was negative and insignificant in the first season $\left(\mathrm{r}_{2}=-0.0622^{\mathrm{ns}}\right)$ and positive and insignificant in the second one $\left(\mathrm{r}_{2}=0.3622^{\mathrm{ns}}\right)$. The coefficient of determination percentages were 18.76 and $41.48 \%$ during 2015 and 2016 growing seasons, respectively.

\section{Cotton seed bug, $O$. hyalinipennis}

There was a negative correlation between temperature and the population density of the cotton seed bug on okra plants being insignificant in the first season $\left(-0.1786^{\mathrm{ns}}\right)$ and highly significant in the second one $\left(r_{1}=-\right.$ $0.7370^{* * * *}$ ). As for relative humidity, it was positive insignificant in the first season of the study $\left(\mathrm{r}_{2}=0.0651^{\mathrm{ns}}\right)$ and positive and significant in the second one $\left(r_{2}=0.5125^{*}\right)$. The coefficient of determination clearly shows that the two considered weather factors affected the population density of $O$. hyalinipennis by 3.19 and $54.31 \%$ during the two mentioned seasons, respectively.

\section{Cotton aphid, A. gossypii}

There were positive and insignificant correlation relationships between the weekly numbers of the cotton aphid and mean temperature in both seasons, whereas $r_{1}$ valued $0.4117^{\mathrm{ns}}$ and $0.2770^{\mathrm{ns}}$ in the first and second seasons, successively. Relative humidity showed negative and insignificant effect, with $\left(\mathrm{r}_{2}\right)$ value of $-0.0368^{\mathrm{ns}}$ in the first season, while in the second one it was positive and insignificant with $\left(\mathrm{r}_{2}\right)$ value of $0.2284^{\mathrm{ns}}$. The coefficient of determination percentages of the two tested weather factors were 18.21 and $41.47 \%$ for the two growing seasons, respectively.

\section{Cotton leafhopper, E. lybica}

E. lybica population had positive and insignificant correlation with the mean temperature, where $\mathrm{r}_{1}=0.2954^{\mathrm{ns}}$ and $0.4090^{\mathrm{ns}}$ during the two growing seasons, respectively. Also, relative humidity showed positive and insignificant correlation $\left(\mathrm{r}_{2}=0.0330^{\mathrm{ns}}\right.$ and $\left.0.1564^{\mathrm{ns}}\right)$ in the experimented seasons, subsequently. The $\mathrm{CD}(\%)$ for temperature and relative humidity were 10.79 in the first season and $53.70 \%$ in the second one. 
Table 4. Simple correlation, partial regression and coefficient of determination between certain weather factors and the weekly number of the main sucking insect pests and their associated predators on okra plants at Diarb-Nigm district, Sharkia Governorate during 2015 and 2016 growing seasons

\begin{tabular}{|c|c|c|c|c|c|c|c|c|c|c|}
\hline \multirow[t]{3}{*}{ Insect species } & \multicolumn{4}{|c|}{ Simple correlation } & \multicolumn{4}{|c|}{ Partial regression } & \multicolumn{2}{|c|}{ CD (\%) } \\
\hline & \multicolumn{2}{|c|}{2015} & \multicolumn{2}{|c|}{2016} & \multicolumn{2}{|c|}{2015} & \multicolumn{2}{|c|}{2016} & \multirow[t]{2}{*}{2015} & \multirow[t]{2}{*}{2016} \\
\hline & $\mathbf{r}_{1}$ & $\mathbf{r}_{2}$ & $\mathbf{r}_{1}$ & $\mathbf{r}_{2}$ & $\mathbf{b}_{1}$ & $\mathbf{b}_{2}$ & $\mathbf{b}_{1}$ & $\mathbf{b}_{2}$ & & \\
\hline
\end{tabular}

Insect pests

\section{B. tabaci}

O. hyalinipennis

A. gossypii

E. lybica

T. tabaci $-0.0622^{\mathrm{ns}}$

$0.1341^{\mathrm{ns}}$

$0.3622^{\text {ns }}$

0.0439

$-0.7370 * * *$

$-0.1786^{\mathrm{ns}}$

$0.0651^{\mathrm{ns}}$

$-0.0368^{\mathrm{ns}}$

$0.2770^{\text {ns }}$

$0.5125 *$

0.4149

0.7779

0.5416

0.0894

18.76

41.48

0.7678

0.0001

0.0124

0.8677

0.2007

0.2944

3.19

54.31

$0.2954^{\mathrm{ns}}$

$0.0330^{\mathrm{ns}}$

$0.4090^{\mathrm{n}}$

$0.1564^{\mathrm{ns}}$

0.1712

0.8812

0.0527

0.4760

$0.2087^{\text {n }}$

$0.3662^{\mathrm{ns}}$

0.2516

0.6473

0.3392

0.0857

41.47

Insect predators

\begin{tabular}{|c|c|c|c|c|c|c|c|c|c|c|}
\hline M. corollae & $0.3637^{\mathrm{ns}}$ & $0.0065^{\text {ns }}$ & $-0.0828^{\mathrm{ns}}$ & $0.3425^{\mathrm{ns}}$ & 0.0880 & 0.9764 & 0.7693 & 0.2114 & 15.20 & 24.86 \\
\hline C. carnea & $0.1558^{\mathrm{ns}}$ & $-0.0384^{\mathrm{ns}}$ & $0.2185^{\mathrm{ns}}$ & $-0.0878^{\mathrm{ns}}$ & 0.4777 & 0.8617 & 0.4340 & 0.7558 & 2.45 & 7.61 \\
\hline C. septempunctata & $0.1160^{\mathrm{ns}}$ & $0.0103^{\mathrm{ns}}$ & $0.2690^{\mathrm{ns}}$ & $-0.0903^{\mathrm{ns}}$ & 0.5982 & 0.9627 & 0.3323 & 0.7489 & 1.45 & 12.95 \\
\hline
\end{tabular}

$\mathrm{r}_{1}, \mathrm{~b}_{1}=$ Correlation and partial regression coefficients between mean temperature and number of species.

$\mathrm{r}_{2}, \mathrm{~b}_{2}=$ Correlation and partial regression coefficients between relative humidity and number of species.

$\mathrm{CD}=$ Coefficient of determination. 


\section{Cotton thrips, T. tabaci}

The correlations between $T$. tabaci population and mean temperature were positive and insignificant $\left(\mathrm{r}_{1}=0.2491^{\mathrm{ns}}\right.$ and $\left.0.2087^{\mathrm{ns}}\right)$ in both seasons, successively. In regard to relative humidity, the correlation was negative and insignificant in the first season $\left(r_{2}=-0.1008^{\text {ns }}\right)$ and positive and insignificant in the second one $\left(\mathrm{r}_{2}=0.3662^{\mathrm{ns}}\right)$. The coefficient of determination percentages of the two studied weather factors were 6.23 and $54.31 \%$ for the two successive seasons, consecutively.

\section{Insect predators}

\section{Syrphus fly, M. corollae}

The weekly number of $M$. corollae had positive and insignificant correlation with the mean temperature $\left(r_{1}=0.3637^{\text {ns }}\right)$ in the first season, while in the second season it was insignificantly negative $\left(\mathrm{r}_{1}=-0.0828^{\mathrm{ns}}\right)$. Relative humidity showed positive and insignificant correlations $\left(\mathrm{r}_{2}=0.0065^{\mathrm{ns}}\right.$ and $\left.0.3425^{\mathrm{ns}}\right)$ for both seasons, respectively. The CD (\%) values for temperature and relative humidity were 15.20 in the first season and $24.86 \%$ in the second one.

\section{Green lacewing, $C$. carnea}

The obtained results show positive and insignificant correlations between mean temperature and the population of C. carnea $\left(\mathrm{r}_{1}=\right.$ $0.1558^{\mathrm{ns}}$ and $0.2185^{\mathrm{ns}}$ ) during the two seasons, respectively. In case of relative humidity the correlations were negative and insignificant $\left(\mathrm{r}_{2}=\right.$ $-0.0384^{\mathrm{ns}}$ and $-0.0878^{\mathrm{ns}}$ ) during the two seasons, respectively. The coefficient of determination percentages for temperature and relative humidity were 2.45 and $7.61 \%$ in 2015 and 2016 growing seasons, successively.

\section{Eleven-spotted ladybird bettle, C. undecimpunctata}

The correlation relationships between $C$. undecimpunctata population and mean temperature were positive and insignificant $\left(\mathrm{r}_{1}=\right.$ $0.3397^{\mathrm{ns}}$ and $0.1654^{\mathrm{ns}}$ ) in the two experimented seasons, respectively. While the correlations respecting relative humidity proved to be insignificantly negative $\left(r_{2}=-0.1604^{\text {ns }}\right)$ during the first season and insignificantly positive in the second one $\left(r_{2}=0.0248^{\text {ns }}\right)$. The coefficient of determination percentages of the two studied weather factors were 11.75 and $11.22 \%$ for the two growing seasons, consecutively.

\section{Seven-spotted ladybird bettle, C. septempunctata}

The correlation coefficients between C. septempunctata population and mean temperature were positive and insignificant $\left(\mathrm{r}_{1}=\right.$ $0.1160^{\text {ns }}$ and $0.2690^{\text {ns }}$ ) in the two successive seasons, respectively. Relative humidity showed positive and insignificant influence $\left(\mathrm{r}_{2}=\right.$ $0.0103^{\text {ns }}$ ) in the first season, while it was negative and insignificant in the second one $\left(\mathrm{r}_{2}=\right.$ - $\left.0.0903^{\mathrm{ns}}\right)$. The CD (\%) values for temperature and relative humidity were $1.45 \%$ in the first season and $12.95 \%$ in the second one.

The obtained results indicated that weather factors are the most important variable factors affecting the population density of sucking insect pests and their associated predators on okra plants. The present findings are in consonance to those of Rote and Puri (1992) who stated that relative humidity is a contributing factor in the population changes of the phytophagous pests (insects and mites), as well as for their predators on okra and squash plants. Such finding are also in conformity with those of Gogoi and Datta (2000) and Panickar and Patel (2001) who reported that meteorogical parameters play an important role in the population fluctuation of sucking insect pests. And those of Bale et al. (2002) who stated that the most important abiotic factor is temperature which has dominant role in insect pest population variation.

\section{The Ratios Between the Common Predators and the Main Sucking Insect Pests}

As seen in Table 5, the relationships between the previously mentioned common predators and the main sucking insect pests infesting okra plants during the two seasons of study were calculated as predators : preys ratios. The highest predators : preys ratio during the first season of the study $(1: 14.78)$ was recorded in July. In the second season, the highest predators: preys ratio $(1: 8.11)$ was obtained also during July. The seasonal predators : preys ratios were $1: 38.23$ and $1: 37.02$ during the first and second seasons, respectively. In general, the highest mean of predators : preys ratio during the two seasons of the study $(1: 11.43)$ 
Table 5. The ratios between the common predators and the main sucking insect pests on okra plants at Diarb-Nigm district, Sharkia Governorate during 2015 and 2016 growing seasons

\begin{tabular}{|c|c|c|c|c|c|c|c|c|c|}
\hline \multirow[t]{2}{*}{ Month } & \multicolumn{3}{|c|}{2015} & \multicolumn{3}{|c|}{2016} & \multicolumn{3}{|c|}{ General } \\
\hline & $\begin{array}{c}\text { No. of } \\
\text { insect pests }\end{array}$ & $\begin{array}{c}\text { No. of } \\
\text { predators }\end{array}$ & $\begin{array}{c}\text { Predator: } \\
\text { prey }\end{array}$ & $\begin{array}{c}\text { No. of } \\
\text { insect pests }\end{array}$ & $\begin{array}{c}\text { No. of } \\
\text { predators }\end{array}$ & $\begin{array}{c}\text { Predator : } \\
\text { prey }\end{array}$ & $\begin{array}{l}\text { No. of insect } \\
\text { pests }\end{array}$ & $\begin{array}{c}\text { No. of } \\
\text { predators }\end{array}$ & $\begin{array}{c}\text { Predator: } \\
\text { prey }\end{array}$ \\
\hline June & 351 & 13 & $1: 27.00$ & 179 & 5 & $1: 35.80$ & 530 & 18 & $1: 29.44$ \\
\hline July & 1227 & 83 & $1: 14.78$ & 681 & 84 & $1: 8.11$ & 1908 & 167 & $1: 11.43$ \\
\hline August & 2057 & 104 & $1: 19.78$ & 2470 & 100 & $1: 24.70$ & 4527 & 204 & $1: 22.19$ \\
\hline September & 1677 & 13 & $1: 129.00$ & 1961 & 1 & $1: 1961.00$ & 3638 & 14 & $1: 259.86$ \\
\hline October & 2309 & 0 & - & 1386 & 0 & - & 3695 & 0 & - \\
\hline November & 522 & 0 & - & 356 & 0 & - & 878 & 0 & - \\
\hline Total number & 8143 & 213 & & 7033 & 190 & & 15176 & 403 & \\
\hline
\end{tabular}


was recorded during July. The general predators : preys ratio during the two seasons of the study was $1: 37.66$.

Such findings are partially agree with those of El-Khawas and El-Khawas (2008) who determined the predator : prey ratios between the major piercing sucking insect pests and their associated predators on eggplant and squash plants in Sharkia Governorate during 2006 and 2007 growing seasons. Similar trends were found by Ghanim et al. (2010) who calculated the ratio between certain piercing sucking insects and the predator, $C$. undecimpunctata on cotton plants in Dakahlia Governorate and found that the maximum ratio was recorded in September during both 2008 and 2009 growing seasons.

\section{REFERENCES}

Abdel Hamed, N.A., H.S. Shalaan, S.A. Yasin and A.M.M. Abou-Zaid (2011). Effect of some abiotic factors on the population fluctuation of some pests infesting okra plants, with the using of some compounds in their controlling. J. Plant Prot. and Pathol., Mansoura Univ., 2 (4): 407 - 419.

Ahmad, S., R.M. Bhagat, A. Ishtiyaq and K. Amit (2010). Pest complex and their succession on okra Abelmoschus esculentus (L.) Moench. Haryana J. Hort. Sci., 39 (1/2) : $169-171$.

Ahmad, G., S.A. Malik, Z. Mahmood, M.Z. Iqbal and S. Ahmad (2002). Effect of leaf curl disease severity on morphology, yield and fibre characteristic of susceptible lines / cultivar of cotton (G. hirsutum L.). Asian J. Plant Sci., $1: 705-707$.

Ali, H., J. Iqbal, M. Waqar and M. Jamil (2015). Evaluation of indigenous plant extracts against sucking insect pests of okra crop. Pak. Entomol., 37 (1) : 39 - 40.

Allam, I.A.Y. (2014). Some mites and insect species harbouring okra and squash plants in Upper Egypt. M.Sc. Thesis, Fac. Agric Assuit Univ. Egypt., 194.

Asi, M.R., M. Afzal, S.A. Anwar and M.H. Bashir (2008). Comparative efficacy of insecticides against sucking insect pests of cotton. Pak. J. Life Soci. Sci., 6 (2) : 140 142.

Bale, J.S., G.J. Masters, I.D. Hodkinson, C. Awinack, T.M. Bezemer and V.K. Brown (2002). Herbivory in global climatic change research : direct effects of rising temperature on insect herbivores. Global Change Biol., 8: $1-16$.

Bhatangar, P. and P.D. Sharma (1991). Comparative incidence of sucking insect pests on different isogenic lines of cotton variety H777. J. Insect Sci., 4 (2) : 170 - 171.

Biological Control Task Force (2005). Precision agriculture: interrelationships of insect density and physiological variation in upland cotton. New Mexico State Univ., Las cruced, NM 88003.

Costat Software Microcomputer Program Analysis (1990). Version 4 - 20 Cohort Software, Berkley CA, USA.

El-Khawas, S.A.M. and M.A.M. El-Khawas (2008). Interactions between Aphis gosypii Glover and the common predators in eggplant and squash fields, with evaluating the physiological and biochemical aspects of biotic stress induced by two different aphid species infesting squash and cabbage plants. Aust. J. Basic and Appl. Sci., 2 (2) : 183 193.

Ghanim, A.A., A.H. Abdel-Salam, S.A. Emara and R.M. Radwan (2010). Evaluation of release Coccinella undecimpunctata $\mathrm{L}$. for controlling certain piercing-sucking insects infesting cotton fields at Manzala District, Dakahlia Governorate J. Plant Prot. and Pathol., Mansoura Univ., 1 (6) : 357 - 368.

Gogoi, B. and C. Datta (2000). Seasonal abundance of cotton jassid, Amrasca biguttula biguttula Ishida on okra. J. Agric. Sci., $13: 22-26$.

Gopalan, C., S.B.V. Sastri and S. Balasubramaniam (2007). Nutritive value of Indian foods. National Inst. Nutr. (NIN). ICMR, India.

Hammad, K.A.A. and A.M. Mohsen (2000). Insects infesting roselle and their associated natural enemies in newly reclaimed sandy land. Egypt J. Appl. Sci., 15 (7) : 618 - 642. 
Harrison, B.D., Y.L. Live, S. Khalid, S. Hamed, G.W. Otim Nape and D.J. Robinson (1997). Detection and relationship of cotton leaf curl virus and allid white fly transmitted Gemini viruses accruing in Pakistan. Ann. Appl. Biol., 130 : 61 - 75.

Henn, T. and R. Weinzierl (1990). Alternatives in insect pest management. Beneficial Insects and Mites. Llinois Univ., Circular, 1298 : 24.

Hoffmann, M.P. and A.C. Frodsham (1993). Natural enemies of vegetable insect pests. Cooperative Extension, Comell Univ., Ithaca, $\mathrm{Ny}: 63$.

Imam T.S., A.U. Yusuf and M.D. Mukhtar (2010). A survey of some insect pests of cultivated vegetables in three selected irrigation areas along Jakara river, Kano, Nigeria. Int. J. Biol. Chem. Sci., 4 (2) : 400 406.

Khan, I.A., S. Ashfaq, R. Akbar, S. Hussain, K. Habib, W. Fayez, M. Saeed, A. Farid, I. Ali, M. Alam and R.A. Shah (2015). Population dynamics of insect pests and their natural enemies on okra, Hibiscus esculentus L. (Malvales : Malvaceae), in Peshawar, Pakistan. J. Entomol. and Zool. Studies, 3 (6): $88-90$.

Khan, S.M. and Z. Ullah (1994). Population dynamics of insect pests of cotton in Dera Ismail Khan. Sarhad J. Agric., 10 : 285- 290.

Kumawat, R.L., B.L. Pareek and B.L. Meena (2000). Investigation on the seasonal incidence of jassid (Amrasca biguttula biguttula). Ann. Biol., 16 (2) : 167 - 169.
Pal, S., B.M. Tarak and M. Palash (2013). Incidence of insect pests on okra, Abelmoschus esculentus (L.) Moench in Red Lateritic Zone of West Bengal. J. Plant Prot. Sci., 5 (1) $59: 64$.

Panickar, B.K. and J.R. Patel (2001). Population dynamics of different species of thrips on chili, cotton and pigeon pea. Indian $\mathrm{J}$. Entomol., 63 (2) : 170 - 175.

Pathon, N.P., T.M. Bharpoda and P.K. Borad (2018). Record of coccinellids, Scymnus spp. (Coleoptera : Coccinellidae) predating on red spider mite (Tetranychus urticae Koch) in okra Abelmoschus esculentus (L.) Moench in middle Gujarat. Adv. in Life Sci., 5 (17) : $6973-6974$.

Rote, N.B. and N. Puri (1992). Effect of fertilizer application on incidence of whitefly on different cotton cultivars. J. Maharashtra Agric. Univ., $17: 45$ - 48.

Singh, V., A. Jha, S. Verma, V.K. Mishra and S.S. Singh (2013). Population dynamics of sucking insect pests and its natural enemies on okra agro-ecosystem in Chitrakoot region. Africa J. Agric. Res., 8 (28) : 3814 - 3819.

Solangi B.K. and M.K. Lahor (2007). Effect of some insecticides on the population of insect pests and predators on okra. Asian J. Plant Sci., 6 (6) : 920 - 926.

Varmudy, V. (2011). Marking survey need to boost okra exports. Department of Economics, Vive Kannda Collage, Puttur, Karnataka, India. 


\title{
الآفات الحثرية الماصة الرئيسية والمفترسات المصاحبة لها على نباتات البامية
}

\author{
هبه عبد الله إسماعيل \\ معهد بحوث وقاية النباتات ـ مركز البحوث الزر اعية ـ الدقي - جيزة ـ مصر
}

أُجريت هذه الدراسة بهدف حصر وتقدير الكثافة العددية للآفات الحشرية الماصة الرئيسية التى تصيب نباتات البامية

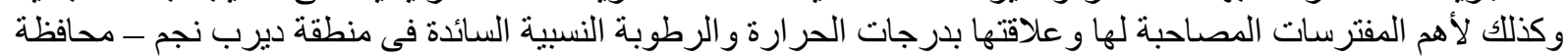

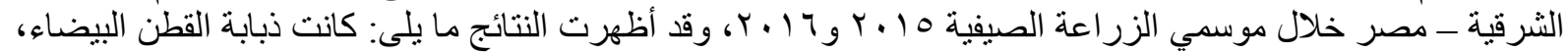

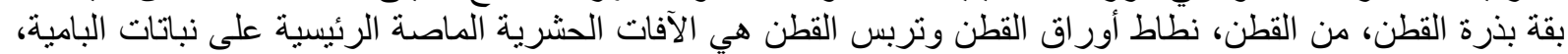

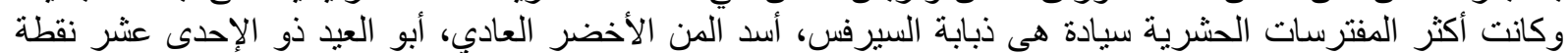

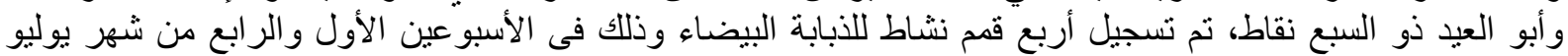

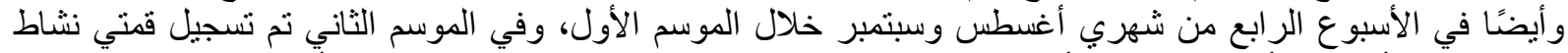

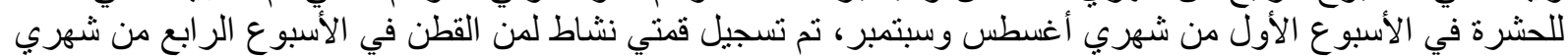

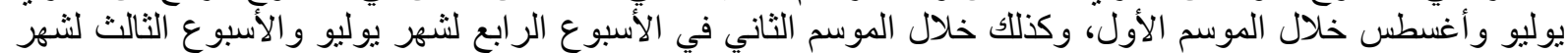

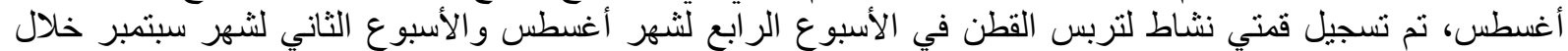

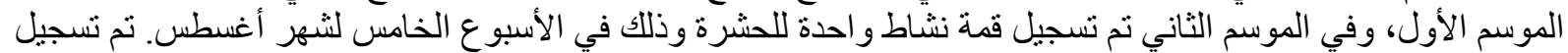

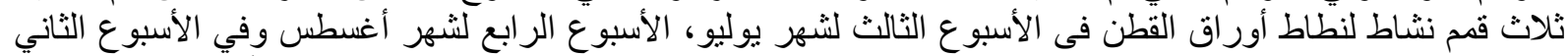

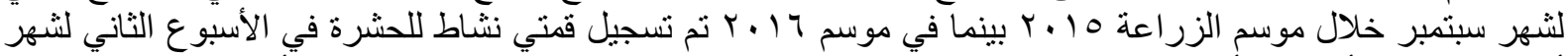

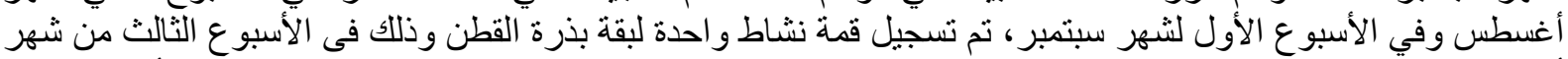

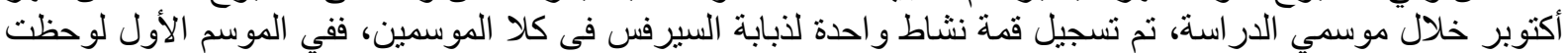

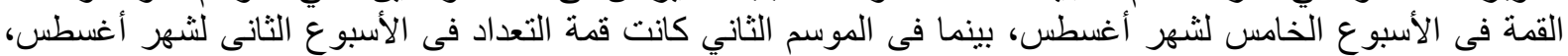

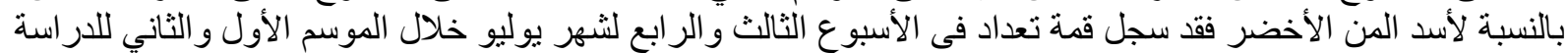

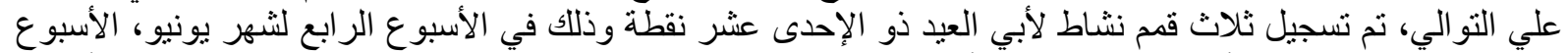

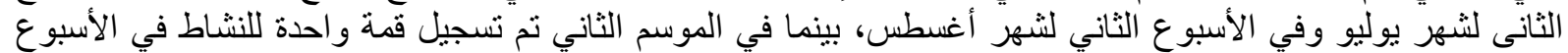

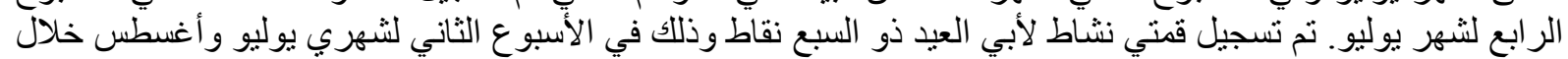

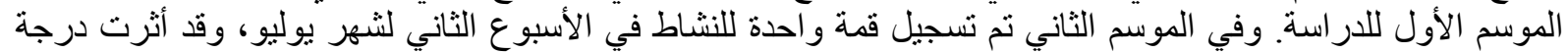

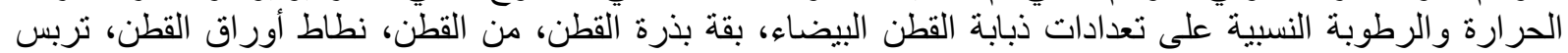

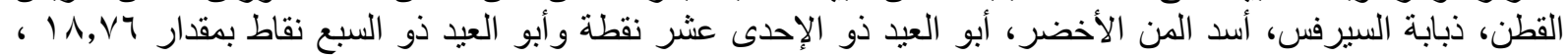
9

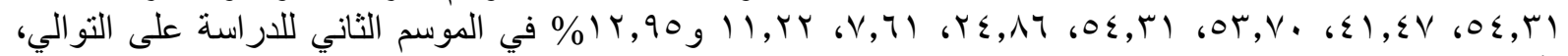
و أيضًا تم تقدير نسب المفترسات إلى الكى الفرائس. 